\title{
HUBUNGAN ANTARA POLA ASUH ORANG TUA DENGAN KECERDASAN EMOSIONAL SISWA
}

\author{
Dendy Saeful Zen M.F ${ }^{1)}$, Lina Novita ${ }^{1)}$ \\ ${ }^{1)}$ Universitas Pakuan, Bogor, Indonesia \\ e-mail korespondensi : dendy.saepul.zein@unpak.ac.id
}

diterima: 05 Juli 2018; direvisi: 24 Agustus 2018; disetujui: 19 September 2018

\begin{abstract}
The purpose of this study is to determine the relationship between parenting towards students' eemotional intelligence. The researsh applies survey method with correlation approach. The data are obtained from the population sample of Pondok Rumput elementary school, Bogor. The result of the trial shows that parenting variable consisting of 50 items tested have 37 valid items, 13 items are not valid with realibility coefficient of 0.781 . Meanwhile, emotional intelligence variable consisting of 50 items tested have 35 valid items, and 15 items are not valid with realibility coefficient of 0.804 . The result of the study shows that there is correlation between emotional intelligent towards parenting based on the statistical analysis. Hence, one of the efforts to develop the students' emotional intelligence is by improving parental care.
\end{abstract}

Keywords: parenting, emotional intelligence.

\section{PENDAHULUAN}

Kecerdasan emosioanal merupakan salah satu kecerdasan siswa yang sangat perlu diperhatikan karena beriirangan perkembangan yang terjadi pada tahapan perkembangan individu seseorang dalam mengahadapi perkembangan selanjutnya maka keluarga khususnya orang tua sebagai orang-orang terdekat hendaknya mengembangkan kecerdasan emosional ini semaksimal mungkin yaitu melalui pola asuh dan tingkah laku yang lebih menekankan pada pentingnya perasaan, selain itu dalam mengatasi serangkaian emosi sebaiknya dengan pengendalian diri bukan dengan tindakan impulsif, membantu siswa dalam mengatasi dan mengenali emosi serta perilakunya tanpa tindakan yang memaksa melainkan tetap mendengarkan pendapat dari siswa.

Lingkungan keluarga terutama orang-orang terdekat sangat berpengaruh dalam mengembangkan kecerdasan emosional pada siswa karena keluarga merupakan lingkungan pendidikan yang pertama dan utama yang dimana soorang anak pertama hidup di dunia ini adalah di lingkungan keluarga. Dikatakan keluarga sebagai pendidikan yang pertama karena di dalam keluargalah proses pendidikan untuk pertama kalinya diterapkan kepada siswa, demikian pula dikatakan keluarga sebagai pendidikan yang utama, karena siswa banyak menghabiskan waktunya di dalam keluarga, sehingga segala bentuk perilaku, sikap dan berbagai peristiwa yang terjadi di dalam keluarga, akan dengan mudah terekam di dalam ingatan siswa dan akan sangat berpotensi pula untuk diikuti atau ditiru entah itu positif ataupun negatif. Maka dari itu orang tua sebagai figur yang dapat dicontoh oleh siswa, hendaknya senantiasa menunjukkan etika dan pengendalian emosi yang baik, agar orang tua dapat dijadikan sebagai suri tauladan yang baik.

Mengingat bahwa kecerdasan emosional ini sangat dipengaruhi oleh pendidikan di dalam keluarga khususnya pola asuh yang diterapkan oleh orang tua, siswa yang dibesarkan dalam kondisi yang aman dan nyaman, dimana orang tua selalu memberikan dukungan dan dorongan serta menghargai pendapat, maka akan membentuk pribadi siswa yang tangguh, berkarakter, percaya diri, mudah bergaul dengan orang lain serta mampu mengontrol dan mengendalikan emosinya atau dengan kata lain siswa memiliki kecerdasan emosional yang baik.

Berdasarkan hasil observasi yang telah dilakukan di Sekolah Dasar Negeri Pondok Rumput Kota Bogor menunjukkan bahwa dari dua kelas yang diteliti yaitu kelas VIA dan VIB, terdapat beberapa perilaku yang cenderung mengindikasikan adanya beberapa siswa yang mengalami kesulitan secara emosional, dimana sebagian dari mereka terlihat pemurung, agresif, dan kurang mengindahkan sopan santun, selain itu mereka terlihat kurang percaya diri, pemalu dan impulsif. Berdasarkan hasil wawancara dengan wali kelas VI, ditemukan beberapa fakta, bahwa beberpa siswa di kelas VIA dan VIB mengalami kesulitan secara emosional, dan ternyata kondisi ini dilatar belakangi oleh pola asuh orang tua dan kondisi keluarga yang bervariasi. Adapun jumlah tersebut dapat diuraikan sebagai berikut: yaitu terdapat beberapa siswa yang pemurung, dimana kebanyakan dari mereka dilatar belakangi oleh kondisi yang tertekan secara sikologis akibat orang tuanya menerapkan pola asuh yang keras, memaksakan kehendak sendiri atau otoriter, selain itu terdapat siswa-siswa yang dikategorikan agresif, impulsif dan kurang mengindahkan sopan santun, dimana jumlah ini diklasifikasikan lagi ke dalam dua kelompok, diantaranya diakibatkan oleh kondisi orang tua yang broken home entah itu perceraian ataupun salah satu orang tuannya meninggal dunia, sementara sisanya dilatar belakangi oleh pola asuh orang tua yang cenderung kurang peduli dan terlalu bebas hal ini disebabkan orang tua terlalu sibuk dengan pekerjaannya, dan oleh karena kurangnya perhatian dari orang tuanya tersebut, maka mereka berusaha mendapatkan perhatian dari orang lain dengan cara 
menunjukkan perilaku yang agresif, impulsif dan kurang mengindahkan sopan santun.

Selanjutnya terdapat beberapa siswa yang cenderung pemalu dan kurang percaya diri, yaitu diantaranya disebabkan oleh kombinasi pola asuh orang tua yang otoriter dan kurang peduli atau terlalu bebas. Di samping siswasiswa tersebut yang mengalami kesulitan secara emosi, terdapat pula siswa-siswa yang dikategorikan kondisi emosinya baik-baik saja atau stabil, siswa-siswa ini terlihat percaya diri, mudah bergaul, ceria dan berprestasi di sekolah, dimana hal ini tentunya dipengaruhi pula oleh pola asuh orang tuanya yang cenderung demokrasi yaitu selalu menghargai pendapat namun tetap menerapkan peraturan secara tegas dengan diberikan pengertian terlebih dahulu.

Kondisi keluarga yang harmonis akan bersinergi dengan energi yang positif sehingga menghasilkan suatu emosi yang stabil, dan jika begitu maka akan menciptakan pula kondisi yang aman dan nyaman di dalam lingkungan rumah, oleh karena itu dari keharmonisan keluarga tersebutlah akan terbentuk siswa yang berkpribadian dan cerdas secara emosional.

Berdasarkan uraian di atas, maka peneliti tertarik untuk melaksanakan penelitian dengan judul Hubungan antara Pola Asuh Orang Tua dengan Kecerdasan Emosional Siswa di Sekolah Dasar Pondok Rumput Kota Bogor. Masalah penelitian dibatasi pada beberapa hal yang berkaitan dengan pola asuh orang tua sebagai variabel bebas dan kecerdasan emosional siswa sebagai variabel terikat. Rumusan masalah yaitu apakah terdapat hubungan antara pola asuh orang tua dengan kecerdasan emosional siswa kelas VIA dan VIB di Sekolah Dasar Negeri Pondok Rumput Kota Bogor?

Dilihat dari tiga ranah yang biasa digunakan dalam dunia pendidikan, yaitu ranah kognitif, afektif dan psikomotorik, maka emosi termasuk ke dalam ranah afektif. Pengaruh dari emosi dapat terlihat pada fungsi-fungsi psikis lainnya, seperti mengamati, memberi tanggapan, cara berpikir dan ketiak seseorang berkeinginan. Seseorang akan mampu melakukan pengamatan atau pemikiran dengan baik jika disertai dengan emosi yang baik pula. Emosi positif memiliki andil dalam tanggapan yang diberikan oleh seseorang. Ketika seseorang memiliki emosi psotif, maka tindakannya pun akan positif. Namun akan terjadi sebaliknya, apabila seseorang tersebut memiliki tanggapan atau emosi. Dengan kata lain emosi sangat mempengaruhi terhadap pola pikir seseorang, sehingga emosi ini haruslah dikendalikan secara cerdas. Perkembangan selanjutnya, para peneliti psikologi melakukan penelitian lebih mendalam mengenai kecerdasan. Lalu muncul pemahaman mengenai cerdas secara emosi atau kecerdasan emosi. Adapun [1] menyatakan bahwa kecerdasan emosi itu sendiri terdiri atas dua kata, yaitu kecerdasan dan emosi.

Pemahaman tentang kecerdasan emosi ini sudah mendapat perhatian [2] yang menyatakan bahwa kemampuan lebih yang dimilki seseorang untuk memotivasi diri sendiri dan bertahan menghadapi frustasi; mengendalikan dorongan hati dan kesenangan yang biasa saja; pengendalian suasana hati dan beban stres yang terjaga, sehingga kemampuan berpkir tetap baik; memiliki empati dan selalu berdoa dapat dikatakan sebagai kecerdasan emosional. Sementara Cooper dan Sawaf yang dikutip oleh [3] dalam mendefinisikan kecerdasan emosional yaitu, "Emotional intelligence is the ability to sense,understand, and effectively apply the power and acumen of human energy, information, connection, and influence". Uraian di atas dapat diartikan bahwa kecerdasan emosional adalah kemampuan merasakan, memahami, dan secara selektif menerapkan daya dan kepekaan emosi sebagai sumber energi manusia, informasi, hubungan dan pengaruh.

Kedua pendapat tersebut, dapat dimaknai bahwa kecerdasan emosi menuntut seseorang dalam mengelola perasaan, dalam arti mampu belajar mengakui, menghargai perasaan pada diri sendiri dan orang lain serta menanggapi dengan tepat, menerapkan secara efektif dalam kehidupan sehari-hari.

Adapun Aspek-aspek emosional dikemukakan oleh Jersild yang dikutip oleh [4] terdiri dari: (1) cinta / kasih sayang, (2) gembira, (3) kemarahan dan permusuhan, (4) ketakutan dan kecemasan. Berikutnya Goleman yang dikutip oleh [3] menjabarkan daftar emosi sebagai berikut: amarah, bringas, mengamuk, benci, marah besar, jengkel, kesal hati, terganggu, rasa pahit, berang, tersinggung, bermusuhan, kekerasan, kesedihan, tidak tenang, ngeri, sampai dengan paling parah, fobia, dan panik, kenikmatan, bahagia, gembira, ringan, puas, riang, senang, terhibur, bangga, kenikmatan indrawi, takjub, rasa terpesona, rasa puas, rasa terpenuhi, rasa girang, senang, senang sekali, cinta, penerimaan, persahabatan, kepercayaan, kebaikan hati, rasa dekat, bakti, hormat, kasmaran, kasih, terkejut, terkesiap, takjub, terpana, jengkel, hina, jijik, muak, tidak suka, tidak enak perasaan, malu, rasa salah, malu hati, kesal hati, sesal, aib, hati hancur lebur, perasaan sedih atau dosa yang mendalam.

Di samping itu, [5] mengemukakan, bahwa komponen-komponen dari keterampilan intrapersonal terdiri atas: (1) kemampuan untuk mengenali, memahami, dan menerima segala kelebihan dan kekurangan yang ada pada diri kita (self-awareness and acceptance), (2) kemampuan mengelola emosi-emosi kita (managing emotions), dan (3) kemampuan memotivasi diri sendiri (self-motivation). Sedangkan keterampilan interpersonal terdiri atas: (1) kemampuan mengadakan dan menjaga hubungan baik (relating well) dan (2) kemampuan memantau emosi (emotional mentoring).

Berdasarkan kajian teoretik di atas, maka dapat disintesiskan bahwa kecerdasan emosional adalah kemampuan seseorang dalam memahami emosi diri sendiri dan emosi orang lain, mengenal emosi dan mengelola emosi secara cerdas yakni dapat mengendalikan antara emosi dan rasionalitas dalam waktu yang bersamaan dengan tepat, dimana emosi itu sendiri digunakannya sebagai sumber informasi untuk senantiasa berpikir positif sehingga dapat terealisasikan dalam bentuk sikap dan perilaku yang positif pula atau baik, di samping itu kecerdasan emosional juga saling berhubungan dengan kecerdasan-kecerdasan lainnya yaitu IQ, SQ, CQ, dan AQ. 
Perkembangan kepribadian tidak terlepas dari lingkungan keluarga yang merupakan tempat pertama kali seseorang mengenal dan belajar segala sesuatu dalam kehidupannya. Pendapat Baumrind yang dikutip oleh [6] mendefinisikan pola asuh sebagai pola sikap atau perlakuan orang tua terhadap anak yang masing-masing mempunyai pengaruh tersendiri terhadap perilaku anak antara lain terhadap kompetensi emosional, sosial, dan intelektual anak. Sementara [7] menyatakan bahwa pola asuh adalah cara orang tua mendidik anak dan membesarkan anak yang dipengaruhi oleh banyak faktor. Merujuk pada kedua pendapat di atas, maka dapat dinyatakan bahwa pola asuh merupakan keseluruhan sikap dan perlakuan orang tua kepada anak dalam rangka mendidik, dimana didikan yang diterapkan oleh orang tua tersebut dipengaruhi oleh banyak faktor, sehingga dapat mempengaruhi pertumbuhan dan perkembangan anak, baik dari segi emosional, sosial dan intelektualnya.

Sementar itu Baldwin yang dikutip oleh [8] menambahkan yaitu sikap-sikap demokratis dari orang tua menimbulkan ciri-ciri berinisiatif, tidak penakut, lebih giat, dan lebih bertujuan, tetapi juga memberikan kemungkinan berkembangnya sifat-sifat tidak taat dan tidak mau menyesuaikan diri. Sementara itu Symonds yang dikutip oleh [8] mendapatkan bahwa sikap penolakan orang tua terhadap anak-anaknya, yaitu sikap menyesal dan tidak setuju karena beberapa sebab dengan adanya anak tersebut, maka mudah mengembangkan ciri-ciri agresivitas dan tingkahlaku bermusuhan pada anak-anak tersebut sehingga timbulah sikap tidak peduli dan membebaskan anaknya. Oleh karena itu timbul juga gejala-gejala menyeleweng seperti berdusta, dan mencuri dapat berkembang pada anak karena sikap penolakan dari orang tuanya.

Pola asuh demokratis dapat dikatakan sebagai pola asuh yang ideal, dimana ciri-cirinya yaitu orang tua bersikap lebih bijaksana, kebebasan dan kontrol seimbang sehingga anaknya menjadi lebih percaya diri, inisiatif yang tinggi dan mudah bergaul. Sementara pola asuh yang otoriter memiliki kecenderungan ciri-ciri orang tua yang memaksakan kehendaknya sendiri serta penerapan antara kebebasan dan kontrol sangat tidak seimbang, dimana kontrol lebih tinggi dan kebebasan tidak ada sama sekali, sehingga menjadikan anak tidak percaya diri, sulit bergaul dan tinggkat kecurigaan kepada orang lain sangatlah tinggi. Selain itu ada pula pola asuh permisif (bebas) yang memiliki ciri-ciri orang tua yang tidak peduli, lebih memberikan kebebasan daripada mengontrol anak, sehingga perkembangan kepribadian anak menjadi tidak terarah.

Berdasarkan kajian teoretik di atas, maka dapat disintesiskan bahwa pola asuh orang tua adalah suatu bentuk interaksi antara orang tua dengan anak-anaknya, melalui gaya atau cara pengasuhan yang berbeda-beda antara orang tua yang satu dengan orang tua lainnya, baik itu secara otoriter, permisif, maupun demokratis, dimana semua gaya pengasuhan tersebut masing-masing memberikan dampak atau pengaruh yang besar bagi kepribadian, emosional dan perilaku anak, baik itu bersifat positif ataupun negatif.
Masalah pola asuh orangtua dan kecerdasan emosional ini telah banyak mendapat perhatian, baik di bidang pendidikan [9] maupun non pendidikan [10] Asyik, Ismanto, \& Babakal, mempersoalkan pada subjek anak usia remaja. Dari ketiga penelitian tersebut ditemukan adanya hubungan anatar pola asuh dengan kecerdasan emosional.

\section{METODE PENELITIAN}

Metode yang digunakan dalam penelitian ini adalah metode survai melalui pendekatan korelasional. Metode survai adalah metode yang digunakan untuk mengumpulkan data atau informasi pada variabel penelitian yaitu pola asuh orang tua dan kecerdasan emosional siswa. Ada pun data penelitian ini diperoleh dari cakupan sampel populasi penelitian siswa Sekolah Dasar Negeri Pondok Rumput Kota Bogor.

Adapun dalam penelitian ini menggunakan instrumen penelitian berupa angket. Instrumen angket tersebut masingmasing digunakan untuk mengukur pola asuh orang tua dan kecerdasan emosional siswa. Intrumen berisi pernyataanpernyataan mengenai variabel yang diteliti. Instrumen disusun dalam bentuk pernyataan dengan menggunakan skala likert yang terdiri dari empat rentang skor. Instrumen hanya meminta responden untuk memilih salah satu dari alternatif jawaban pernyataan yang sudah disediakan. Adapun alternatif jawabannya adalah pernyataan positif: (4) Sangat Setuju (SS); (3) Setuju (S); (2) Ragu-Ragu (R); (1) Tidak Setuju (TS). Sedangkan untuk pernyataan negaif: (1) Sangat Setuju (SS); (2) Setuju (S); (3) Ragu-Ragu (R); (4) Tidak Setuju (TS).

\section{HASIL DAN PEMBAHASAN}

Sebelum pelaksanaan penelitian terlebih dahulu dilaksanakan uji coba instrumen, penelitian khusus untuk variabel kecerdasan emosional sebagai variabel bebas dan pola asuh variabel terikat yang dilaksanakan pada $27 \mathrm{Mei}$ 2017. Dimana variabel tersebut diujicobakan kepada 30 responden (siswa) yaitu siswa kelas VC Sekolah Dasar Negeri Pondok Rumput Kecamatan Tanah Sareal Kabupaten Bogor Semester Genap Tahun Pelajaran 2016/2017.

Berdasarkan Hasil uji coba, variabel pola asuh yang terdiri dari 50 butir pernyataan yang diujicobakan diperoleh hasil sebanyak 37 butir soal yang valid dan 13 butir soal tidak valid dengan koefisien realibilitas sebesar 0,781. Sedangkan untuk variabel kecerdasan emosional yang terdiri dari 50 butir pernyataan yang diujicobakan diperoleh hasil sebanyak 35 butir soal yang valid dan 15 butir soal tidak valid dengan koefisien realibilitas sebesar 0,804.

Setelah dilaksanakan uji coba instrumen, selanjutnya peneliti melaksanakan penelitian yang dilaksanakan pada hari Selasa dan Rabu tanggal 14-15 Juni 2017 pukul 09.00 sampai pukul 10.00. Penelitian terdiri dari dua variabel yaitu variabel bebas kecerdasan emosional $(\mathrm{X})$ dan variabel terikat pola asuh orangtua $(\mathrm{Y})$. Untuk instrumen penelitian berupa angket yang sebelumnya telah diujicobakan yang mana diikuti oleh 63 siswa Sekolah Dasar Negeri Pondok Rumput 
Kecamatan Tanah Sareal Kabupaten Bogor Semester Genap Tahun Pelajaran 2016/2017.

Berdasarkan hasil penelitian kedua variabel yang diteliti yaitu variabel kecerdasan emosional (X) dan pola asuh orangtua (Y), maka dapat dianalisis dan dideskripsikan secara statistik deskriptif dengan mean, median, modus, standar deviasi, nilai tertinggi, nilai terendah, varian sampel, skor total, banyak kelas, dan rentang kelas.

\section{a. Deskripsi Data Statistik Deskriptif}

Hasil penelitian yang dilaksanakan pada Hari Selasa dan Rabu, 14-15 Juni 2017 yang melibatkan 63 responden (siswa) yang terdiri dari 15 siswa kelas VA, 16 siswa kelas VB, 16 siswa kelas VC, dan 16 siswa kelas VD Sekolah Dasar Negeri Pondok Rumput Kecamatan Tanah Sareal Kabupaten Bogor Semester Genap Tahun Pelajaran 2016/2017, menunjukkan bahwa dari 37 pernyataan variabel pola asuh didapat skor tertinggi sebesar 136, skor terendah diperoleh sebesar 94, dan jumlah skor keseluruhan (total skor) 6908. Dengan demikian rentang skornya 42. Banyak kelas yang diperoleh 7, sehingga jarak kelas adalah 6 . Kemudian nilai rata-rata skor 109,651 , nilai tengah sebesar 107, skor yang paling sering muncul adalah 113. Dengan nilai varians sampel adalah 70,94 dengan standar deviasi 8,422 .

Deskripsi data hasil penelitian dikelompokan menjadi dua bagian yaitu terdiri dari: data variabel terikat yaitu pola asuh orangtua (Y), dan data variabel bebas kecerdasan emosional (X) yang dideskripsikan dalam bentuk deskripsi statistik.

\section{b. Variabel Pola asuh orangtua}

Berdasarkan perhitungan angket variabel pola asuh orangtua yang terdiri dari 37 butir pernyataan dengan 63 responden, maka didapat hasil sebagai berikut: jumlah skor 6908, skor terendah 94 dan skor tertinggi 136 dengan demikian rentang skor 42, rata-rata skor 109,651, nilai tengah sebesar 109, skor yang paling sering muncul adalah 113, dan jumlah kelas interval sebanyak 7 dengan jarak kelas yaitu 6. Selain itu varians sampel adalah 70,940 dengan standar deviasi 8,42.

Dari data tersebut maka diperoleh interval nilai sebanyak 7 kelas dengan jarak kelas 6. Interval ini dimulai dari skor terendah hingga tertinggi, antara lain: kelas pertama interval nilainya dimulai dari 94-100, kelas kedua dimulai dari 101-107, kelas ketiga dimulai dari 108-114, kelas keempat dimulai dari 115-121, kelas kelima dimulai dari 122-128, kelas keenam dimulai dari 129-135, kelas ketujuh dimulai dari 136-142.

Adapun tabel frekuensi dan histogram data variabel pola asuh orangtua dapat dilihat pada tabel berikut ini:
Tabel 1 Distribusi Frekuensi Data Pola asuh orangtua

\begin{tabular}{cccccc}
\hline No & $\begin{array}{c}\text { Kelas } \\
\text { Interval }\end{array}$ & Batas Kelas & $\begin{array}{c}\text { Titik } \\
\text { Tengah }\end{array}$ & $f_{\text {absolut }}$ & $\begin{array}{c}\mathrm{f}_{\text {relative }} \\
(\%)\end{array}$ \\
\hline 1 & $94-100$ & $93,5-100,5$ & 97 & 9 & 14,28 \\
\hline 2 & $101-107$ & $100,5-106,5$ & 104 & 17 & 26,98 \\
\hline 3 & $108-114$ & $107,5-114,5$ & 111 & 24 & 38,09 \\
\hline 4 & $115-121$ & $114,5-121,5$ & 118 & 8 & 12,69 \\
\hline 5 & $122-128$ & $121,5128,5$ & 125 & 1 & 1,58 \\
\hline 6 & $129-135$ & $128,5-135,5$ & 132 & 3 & 4,76 \\
\hline 7 & $136-142$ & $135,5-142,5$ & 139 & 1 & 1,58 \\
\hline \multicolumn{7}{c}{ Jumlah } \\
\hline
\end{tabular}

Hasil distribusi frekuensi tersebut dapat dilihat pada diagram histogram di bawah ini

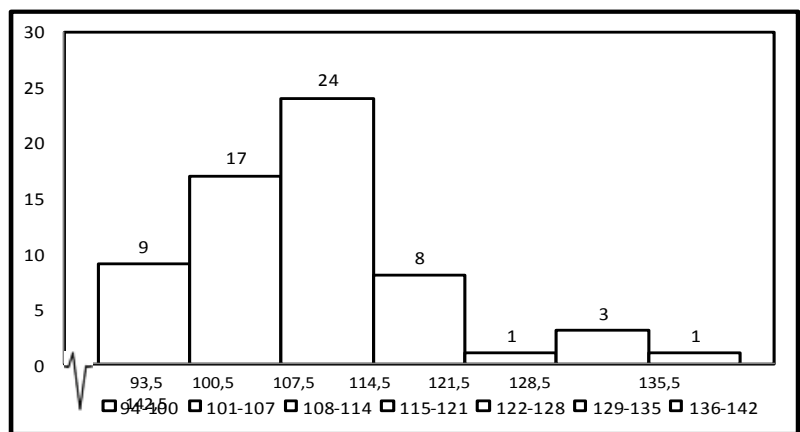

Gambar 1 Diagram Histogram Data Hasil Penelitian Pola Asuh Orangtua

Histogram di atas, menunjukkan bahwa frekuensi tertinggi berada pada kelas interval 107 sampai 114, sedangkan frekuensi terendah berada pada kelas interval 121 sampai 128 dan 135 sampai 142 . Selain itu berdasarkan data statistik deskriptif pola asuh orangtua memiliki nilai rata-rata (mean) sebesar 109,65.

\section{c. Deskripsi Data Variabel Kecerdasan Emosional (X)}

Berdasarkan perhitungan angket variabel kecerdasan emosional yang terdiri dari 35 butir pernyataan dengan 63 responden, maka didapat hasil sebagai berikut: jumlah skor 6665, skor terendah 86 dan skor tertinggi 136 dengan demikian rentang skornya adalah 50, rata-rata skor 105,7 , mediannya sebesar 107, skor paling sering muncul 106, dan jumlah kelas interval sebanyak 7 dengan jarak kelas yaitu 8 . Selain itu nilai varians sampel adalah 82,87 dengan standar deviasi 9,10.

Dari data tersebut maka diperoleh interval sebanyak 7 kelas dengan jarak kelas 8. Interval ini dimulai dari skor terendah hingga tertinggi, antara lain: kelas pertama nilainya dimulai dari 86-93, kelas kedua dimulai dari 94-101, kelas ketiga dimulai dari 102-109, kelas keempat dimulai dari 110-117, kelas kelima dimulai dari 118-125, kelas keenam dimulai dari 126-133, kelas ketujuh dimulai dari 134-141. 
Adapun tabel frekuensi dan histogram data variabel kecerdasan emosional dapat dilihat pada tabel berikut ini:

Tabel 2 Distribusi Frekuensi Data Kecerdasan Emosional (X)

\begin{tabular}{ccccc}
\hline & $\begin{array}{c}\text { Varian yang } \\
\text { diuji }\end{array}$ & Fhitung & Ftabel & Kesimpulan \\
\hline 1. & Y atas X & 1,08 & 3,39 & Homogen \\
\hline \multicolumn{4}{r}{ Uji taraf signifikan Fhitung < Ftabel } \\
\hline
\end{tabular}

Hasil distribusi frekuensi tersebut dapat dilihat pada diagram histogram di bawah ini:

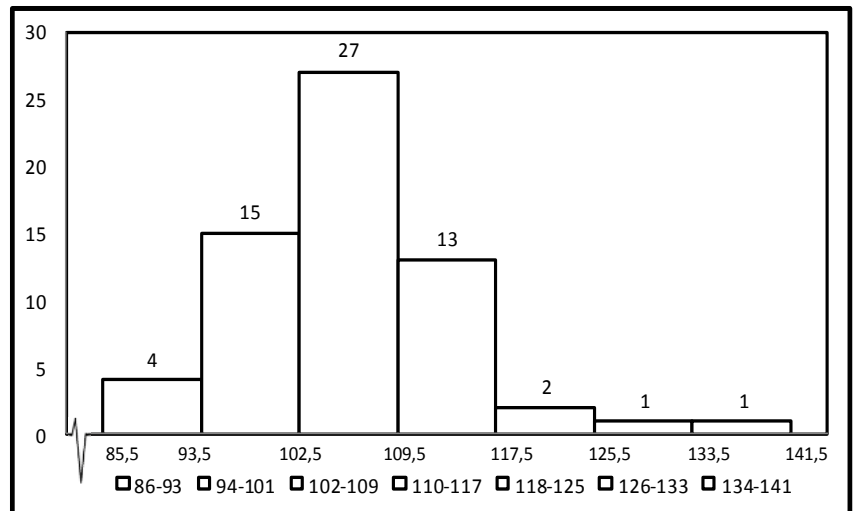

Gambar 2 Diagram Histogram Distribusi Data Hasil

Penelitian Kecerdasan Emosional

Diagram histogram di atas menunjukkan frekuesni tertinggi berada pada kelas interval 102 sampai 109 sedangkan frekuensi terendah berada pada kelas interval 126 sampai 133 dan 134 sampai 141. Selain itu berdasarkan data statistik deskriptif kecerdasan emosional memiliki nilai ratarata (mean) sebesar 105,7.

\section{Pengujian Prasyarat Analisis}

Pengujian Prasyarat Analisis meliputi normalitas galat baku taksiran dan uji coba homogenitas varian. Sesuai dengan jenis data tersebut, uji normalitas galat baku taksiran menggunakan uji Liliefors dan untuk menguji homogenitas menggunakan uji Fisher.

\section{Uji Normalitas Galat Baku Taksiran}

Pengujian normalitas galat baku data taksiran dilakukan untuk mengetahui normal atau tidaknya suatu distribusi data, untuk mengujinya menggunakan Uji Liliefors pada variabel pola asuh orangtua (Y) dan Variabel kecerdasan emosional $(\mathrm{X})$ dengan syarat jika $\mathrm{H}_{\mathrm{o}}=$ Lhitung > Ltabel berarti galat baku taksiran tidak normal dan jika $\mathrm{H}_{\mathrm{o}}=$ Lhitung < Ltabel berarti galat baku taksiran normal.

Berdasarkan uji normalitas dengan menggunakan Liliefors diperoleh Lhitung $=0,0884$. Harga tersebut dibandingkan dengan harga Ltabel $=0,1117$ dan taraf kesalahan 5\%, maka distribusi data kecerdasan emosional (X) dengan pola asuh orangtua (Y) tersebut normal.
Tabel.3 Rangkuman Uji Normalitas Data Kecerdasan Emosional dengan Pola Asuh Orangtua

\begin{tabular}{cccccc}
\hline No & $\begin{array}{c}\text { Kelas } \\
\text { Interval }\end{array}$ & Batas Kelas & $\begin{array}{c}\text { Titik } \\
\text { Tengah }\end{array}$ & $f_{\text {absolut }}$ & $\begin{array}{c}f_{\text {relative }} \\
(\%)\end{array}$ \\
\hline 1 & $86-93$ & $85,5-93,5$ & 89,5 & 4 & 6,34 \\
\hline 2 & $94-101$ & $93,5-101,5$ & 97,5 & 15 & 23,80 \\
\hline 3 & $102-109$ & $101,5-109,5$ & 105,5 & 27 & 42,85 \\
\hline 4 & $110-117$ & $109,5-117,5$ & 113,5 & 13 & 20,65 \\
\hline 5 & $118-125$ & $117,5-125,5$ & 121,5 & 2 & 3,17 \\
\hline 6 & $126-133$ & $125,5-133,5$ & 129,5 & 1 & 1,58 \\
\hline 7 & $134-141$ & $133,5-141,5$ & 137,5 & 1 & 1,58 \\
\hline & & & 63 & $100 \%$ \\
\hline
\end{tabular}

\section{Uji Homogenitas Varians}

Pengujian homogenitas dilakukan untuk mengetahui apakah populasi bersifat homogen atau tidak. Pengujian homogenitas dilakukan dengan Uji Fisher menggunakan varians terbesar dibanding varians terkecil.

Berdasarkan hasil perhitungan uji homogentitas data pola asuh orangtua dan kecerdasan emosional diperoleh fhitung sebesar 1,08 untuk jumlah sampel 63 dan taraf signifikansi $\alpha=0,05$ diperoleh

ftabel sebesar 3,39.

\section{Pengujian Hipotesis Penelitian}

Dalam penelitian ini terdapat dua hipotesis yang diuji melalui metode statistik berupa uji regresi dan korelasi. Adapun data yang diuji berdasarkan perhitungan statistik yang dibantu dengan program Ms. Excel terdiri atas data Kecerdasan Emosional (X) dan Pola asuh orangtua (Y). Data yang dinyatakan normal dan homogen, selanjutnya dilakukan pengujian hipotesis. Pengujian hipotesis dimaksudkan untuk mengetahui apakah hipotesis nol $\left(\mathrm{H}_{0}\right)$ yang akan diajukan diterima atau sebaliknya, pada taraf kepercayaan $\alpha=0,05$ atau $5 \%$.

\section{Analisis Regresi Linier Sederhana}

Untuk memperjelas pengaruh variabel kecerdasan emosional (X) dengan pola asuh orangtua (Y) yang berdasarkan hasil perhitungan uji signifikansi dan dinyatakan dalam bentuk persamaan regresi yaitu $\hat{Y}=a+$ bx. Hubungan $\mathrm{X}$ dengan $\mathrm{Y}$ disajikan dalam bentuk $\hat{\mathrm{Y}}=($ $4,606+1,08 x)$ dengan $X$ adalah signifikan. Dapat dilihat pada diagram pancar berikut.

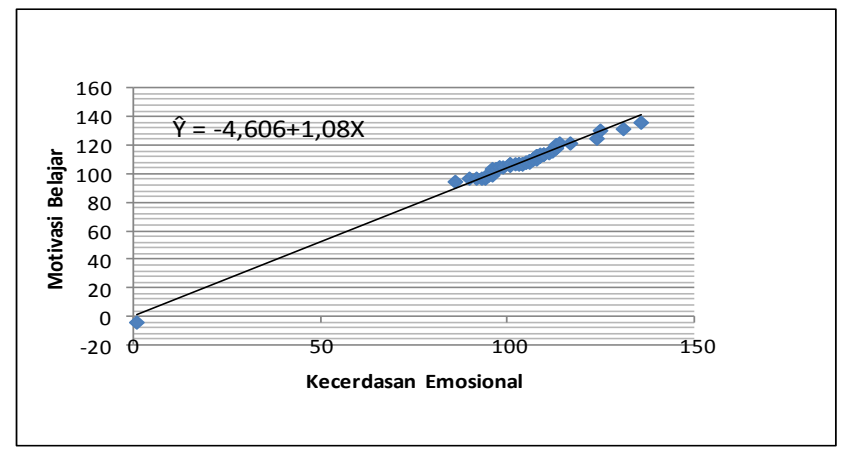

Gambar 3 Diagram pencar hubungan variabel kecerdasan emosional $(\mathrm{X})$ dengan pola asuh orangtua $(\mathrm{Y})$ 
Hasil perhitungan analisis persamaan regresi pada gambar diagram pencar di atas menunjukkan suatu korelasi yaitu terdapat hubungan positif dari variabel kecerdasan emosional dengan pola asuh orangtua. Kebenaran dari hasil regresi tersebut digunakan untuk menguji hipotesis mengenai ada tidaknya hubungan positif kecerdasan emosional (X) dengan pola asuh orangtua (Y). Hal ini ditunjukkan dari persamaan regresi $\hat{\mathrm{Y}}=(-4,606+1,08 \mathrm{x})$, artinya setiap peningkatan 1 unit kecerdasan emosional akan menaikan pola asuh orangtua sebesar 1,08 unit.

\section{Uji Signifikansi Regresi}

Untuk menentukan hipotesis teruji dengan syarat jika $\mathrm{F}_{\text {hitung }}>\mathrm{F}_{\text {tabel }}$. Maka, berdasarkan hasil perhitungan uji signifikansi regresi diperoleh $F_{\text {hitung }}=460,41$ dengan $F_{\text {tabel }}$ $(\alpha=0,05)=4,00$ dan Ftabel $(\alpha=0,01)=7,06$ dengan demikian $\mathrm{F}_{\text {hitung }}>\mathrm{F}_{\text {tabel }}(\alpha=0,01)>\mathrm{F}_{\text {tabel }}(\alpha=0,05)=460,41>7,06>$ 4,00 , berarti hubungan kecerdasan emosional dengan pola asuh orangtua yang ditunjukkan oleh persamaan regresi yaitu sangat signifikan.

\section{Uji Linearitas Regresi}

Pengujian linearitas regresi kecerdasan emosional (X) dengan pola asuh orangtua $(\mathrm{Y})$, didapatkan nilai $\mathrm{F}_{\text {hitung }}=1,33$ sedangkan $(\alpha=0,05)=1,78$ dan $F_{\text {tabel }(\alpha=0,01)}=2,26$ dengan $\mathrm{dk}$ pembilang $(\mathrm{k}-2)=27 \mathrm{dan} d \mathrm{k}$ penyebut $(\mathrm{n}-\mathrm{k})=36$. Untuk pengujian hipotesis nol $\left(\mathrm{H}_{0}\right)$ ditolak jika hipotesis regresi linear $F_{\text {hitung }}>F_{\text {tabel }(\alpha=0,05)}>F_{\text {tabel }(\alpha=0,01)}$ dan jika $F_{\text {hitung }}<F_{\text {tabel }}$ $(\alpha=0,05)<\mathrm{F}_{\text {tabel }}(\alpha=0,01)$ artinya $\mathrm{H}_{\mathrm{a}}$ diterima. Dengan demikian $\mathrm{F}_{\text {hitung }}<\mathrm{F}_{\text {tabel }(\alpha=0,05)}<\mathrm{F}_{\text {tabel }(\alpha=0,01)}=1,33<1,78<2,26$ berarti hipotesis linear diterima. Simpulannya data kecerdasan emosional dan pola asuh orangtua memiliki pola hubungan yang linear.

\section{Uji koefesien korelasi dan koefesien determinasi}

Besarnya hubungan langsung dari variabel kecerdasan emosional (X) dengan pola asuh orangtua (Y) dinyatakan dalam besarnya nilai numerik koefesien korelasi dari kecerdasan emosional (X) ke pola asuh orangtua (Y).

Koefesien korelasi untuk model analisis korelasi sederhana terdiri dari satu variabel terikat dan satu variabel bebas nilainya sama dengan besarnya koefesien korelasi antara kedua variabel tersebut $\left(\rho_{x y}=r_{x y}\right)$.

Oleh karena itu, pengujian hipotesis dilakukan dengan menggunakan korelasi Product Moment (Pearson). Berdasarkan hasil perhitungan diperoleh koefesien korelasi antara kecerdasan emosional (X) dengan pola asuh orangtua (Y) adalah 0,98. Uji keberartian hubungan antara kecerdasan emosional (X) dengan pola asuh orangtua (Y) dihitung dengan uji t. Hasil perhitungan keberartian koefesien tersebut tertera pada tabel 4 .

Dari tabel 4 dapat diketahui besarnya hubungan kecerdasan emosional dengan pola asuh orangtua yaitu sebesar 0,98. Dapat digambarkan hubungan kecerdasan emosional dengan pola asuh orangtua sebagai berikut: Pola asuh orangtua (Y) dihubungkan secara langsung oleh kecerdasan emosional (X), tetapi diluar pola asuh orangtua masih banyak penyebab lain dalam penelitian tidak diukur. Penyebab lain itu dinyatakan oleh variabel residu.

Kekuatan hubungan dari variabel kecerdasan emosional (X) dengan pola asuh orangtua (Y) ditunjukkan oleh koefesien korelasi 0,98. Nilai koefesien korelasi tersebut jika dibandingkan dengan tabel interpretasi $r$ terdapat pada interval koefisien $0,800-1,00$ yang berarti tingkat hubungan kedua variabel penelitian sangat kuat.

Tabel 4 Hasil Pengujian Keberartian Koefesien Korelasi Variabel Kecerdasan Emosional (X) Dengan Pola asuh orangtua (Y)

\begin{tabular}{|c|c|c|c|c|c|c|}
\hline \multirow{3}{*}{ No } & \multirow{3}{*}{$\begin{array}{l}\text { Koefesien } \\
\text { Korelasi }\end{array}$} & \multirow{3}{*}{$\begin{array}{l}\text { Koefesien } \\
\text { Determinasi }\end{array}$} & \multicolumn{3}{|c|}{ Signifikansi } & \multirow{3}{*}{ Kesimpulan } \\
\hline & & & \multirow{2}{*}{$t_{\text {hitung }}$} & \multicolumn{2}{|c|}{$\mathrm{t}_{\text {tabel }}$} & \\
\hline & & & & 0,05 & 0,01 & \\
\hline 63 & 0,98 & 0,95 & 54,6 & 1,67 & 2,39 & $\begin{array}{c}\text { Hubungan } \\
\text { positif yang } \\
\text { signifikan }\end{array}$ \\
\hline
\end{tabular}

Pengujian hipotesis terdapat "hubungan positif dari variabel kecerdasan emosional dengan pola asuh orangtua" menggunakan uji signifikansi kefesien korelasi dengan uji t. Kriteria pengujian signifikansi koefesien korelasi sama dengan koefesien jalur yaitu $t_{\text {hitung }}>t_{\text {tabel, }}$ maka koefesien korelasi dinyatakan signifikan. Berdasarkan hasil perhitungan diperoleh $t_{\text {hitung }}=54,6$ dengan $t_{\text {tabel }(\alpha=0,05)}=1,671$ dan $t_{\text {tabel }(\alpha=0,01)}=2,390$ dengan demikian $t_{\text {hitung }}>t_{\text {tabel }(\alpha=0,05)}>$ $\mathrm{t}_{\text {tabel }(\alpha=0,01)}=54,6>2,390>1,671$, yang berarti koefisien korelasi kecerdasan emosional dengan pola asuh orangtua adalah signifikan, sehingga disimpulkan bahwa terdapat hubungan positif dan signifikan dari kecerdasan emosional dengan pola asuh orangtua.

Hasil analisis data pengujian hipotesis diperoleh data bahwa terdapat hubungan yang positif antara kecerdasan emosional dengan pola asuh orangtua. Hal ini menunjukkan bahwa hipotesis penelitian diterima, berarti kecerdasan emosional memberikan konstribusi dalam pola asuh orangtua.

Hubungan dari kecerdasan emosional dengan pola asuh orangtua secara analisis statistik ditunjukkan dengan hasil uji signifikansi dan regresi dengan persamaan regresi $\hat{Y}$ $=-4,606+1,08 x$. Hal ini berarti bahwa setiap kenaikan satu unit variabel kecerdasan emosional akan menyebabkan peningkatan pada pola asuh orangtua sebesar 1,08 unit.

Kekuatan hubungan antara kecerdasan emosional dengan pola asuh orangtua ditunjukkan dengan koefesien korelasi sebesar 0,98. Harga koefesien tersebut menunjukkan bahwa terdapat hubungan yang sangat kuat antara variabel kecerdasan emosional dengan pola asuh orangtua.

Besarnya konstribusi kecerdasan emosional dengan pola asuh orangtua ditunjukkan oleh koefesien $\left(\mathrm{r}^{2}\right)$ sebesar 0,95 dengan koefesien determinasi sebesar 95\%. Hal ini berarti bahwa penaikan atau penurunan pola asuh orangtua dipengaruhi oleh tingkat kecerdasan emosional sebesar 95\%, sedangkan sisanya $5 \%$ dipengaruhi oleh faktor-faktor lainnya.

Hasil perhitungan tersebut didukung hasil penelitian Paramita Dewi yang berjudul Hubungan Kecerdasan Emosi 
dan Pola asuh orangtua Kelas V SD Negeri Se-Kecamatan Klaten Tengah menyimpulkan bahwa terdapat hubungan positif antara kecerdasan emosi dan pola asuh orangtua dengan kemandirian belajar dengan nilai Fhitung sebesar 394,407. Selain itu, hasil penelitian yang dilakukan oleh Luqman yang berjudul Hubungan Antara Kecerdasan Emosi dengan Pola asuh orangtua dilakukan pada mahasiswa psikologi UIN Malang yang berjumlah 60 menunjukkan bahwa sebagian besar mahasiswa memiliki kecerdasan emosi dan pola asuh orangtua menengah (sedang). Dan korelasi dua variabel $r_{x y}=0,847$.

Berdasarkan perhitungan analisis statistik tersebut, dapat dikatakan bahwa siswa yang kecerdasan emosionalnya rendah, memiliki pol asuh orangtua yang rendah pula, demikian sebaliknya siswa yang kecerdasan emosionalnya tinggi, maka pola asuh orangtuanya juga tinggi.

Pendapat Baumrind yang dikutip oleh [6] mendefinisikan pola asuh sebagai pola sikap atau perlakuan orang tua terhadap anak yang masing-masing mempunyai pengaruh tersendiri terhadap perilaku anak antara lain terhadap kompetensi emosional, sosial, dan intelektual anak. Sementara [7] menyatakan bahwa pola asuh adalah cara orang tua mendidik anak dan membesarkan anak yang dipengaruhi oleh banyak faktor. Merujuk pada kedua pendapat di atas, maka dapat dinyatakan bahwa pola asuh merupakan keseluruhan sikap dan perlakuan orang tua kepada anak dalam rangka mendidik, dimana didikan yang diterapkan oleh orang tua tersebut dipengaruhi oleh banyak faktor, sehingga dapat mempengaruhi pertumbuhan dan perkembangan anak, baik dari segi emosional, sosial dan intelektualnya.

Kemampuan seseorang dalam mengelola emosi diungkapkan [11] yang dikatakan seseorang memiliki kecerdasan emosi jika mampu memotivasi diri sendiri, mampu bertahan menghadapi frustasi, pengendalian diri dan memiliki kesenangan yang wajar, memiliki suasana hati yang diatur dengan baik dan beban stres yang terjaga sehingga mampu berpkir, memiliki empati dan mampu berdoa dengan baik.

Hubungan positif antara kecerdasan emosional dengan pola asuh orangtua berdasarkan penelitian yang diteliti ditunjukkan dari analisis statistik yang menghasilkan keberartian regresi Fhitung $=1,08<$ Ftabel $=3,39$. Hal tersebut menunjukkan adanya hubungan antara kecerdasan emosional dengan pola asuh orangtua sedangkan koefisien determinasi (KD) 95\% diperoleh keterangan objektif bahwa terdapat hubungan antara kecerdasan emosional dengan pola asuh orangtua.

Berdasarkan uraian di atas, menunjukkan terdapat hubungan antara kecerdasan emosional dengan pola asuh orangtua berdasarkan analisa statistik di atas secara logika dan dapat dibuktikan. Jadi, salah satu upaya mengembangkan kecerdasan emosional pada diri siswa sejak dini, yaitu dengan meningkatkan pola asuh orang tua. Hasil penelitian tersebut memiliki kesamaan dengan jurnal penelitian yang ditulis [12].

\section{SIMPULAN}

Berdasarkan hasil pengolahan data, hasil hipotesis dan pembahasan hasil penelitian, maka dapat disimpulkan bahwa hubungan dari kecerdasan emosional dengan pola asuh orangtua secara analisis statistik ditunjukkan dengan hasil uji signifikansi dan regresi dengan persamaan regresi $\hat{Y}$ $=-4,606+1,08 x$. Hal ini berarti bahwa setiap kenaikan satu unit variabel kecerdasan emosional akan menyebabkan peningkatan pada pola asuh orangtua sebesar 1,08 unit. Kekuatan hubungan antara kecerdasan emosional dengan pola asuh orangtua ditunjukkan dengan koefesien korelasi sebesar 0,98. Harga koefesien tersebut menunjukkan bahwa terdapat hubungan yang sangat kuat antara variabel kecerdasan emosional dengan pola asuh orangtua. Besarnya konstribusi kecerdasan emosional dengan pola asuh orangtua ditunjukkan oleh koefesien $\left(r^{2}\right)$ sebesar 0,95 dengan koefesien determinasi sebesar 95\%. Hal ini berarti bahwa penaikan atau penurunan kecerdasan emosional dipengaruhi oleh tingkat pola asuh orang tua sebesar 95\%, sedangkan sisanya $5 \%$ dipengaruhi oleh faktor-faktor lainnya.

\section{REFERENSI}

[1] Puspasari, Amaryllia. Emotional Intelligent Parenting. Jakarta : Elex Media Komputindo. 2009.

[2] Goleman, Daniel. Kecerdasan Emosional. Jakarta : Gramedia Pustaka Utama. 2000.

[3] Efendi, Agus. Revolusi Kecerdasan Abad 21. Bandung : Alfabeta. 2005.

[4] Sunarto. Perkembangan Peserta Didik. Jakarta : Rineka Cipta. 2006.

[5] Bahaudin, Taufik. Brainware Management. Jakarta : Elex Media Komputindo. 1999.

[6] Yusuf, Syamsu. Psikologi Perkembangan Anak dan Remaja. Bandung : Remaja Rosdakarya. 2011.

[7] Markum, A. Ilmu Kesehatan Anak. Jakarta: Gaya baru. 2002.

[8] Gerungan. Psikologi Sosial. Bandung : Aditama. 2010.

[9] Ristiyadi, Wawan., Yudiernawati, Atti., Maemunah, Neni. 2017.

[10] Asyik, Fatmawati M., Ismanto, Amatus Yudi., Babakal, Abram. Hubungan Pola Asuh Orang Tua dengan Kecerdasan Emosional pada Anak Usia Remaja Di Kelurahan Soasio Kota Tidore Kepulauan. ejournal Keperawatan (e-Kp). Vol 3 No. 2. 2015.

[11] Uno, B. Orientasi Baru Dalam Psikologi Pembelajaran. Jakarta: Bumi Aksara. 2012

[12] Chandri, Desy Makart., R,. Marmawi, dan Yuniarni, Desni. Pengaruh Pola Asuh Orang Tua Terhadap Kecetsasan Anak Usia 5-6 Tahun. Tersedia pada jurnal.untan.ac.id/index.php/jpdpb/article/download/ 5784/6594. 2016. 